\title{
Una Religio in Rituum Varietate: Religious Pluralism, the Qur'an, and Nicholas of Cusa
}

\author{
Pim Valkenberg
}

This essay will focus on the possible origins of just five words. These words, however, might have been the most famous words that Nicholas of Cusa ever wrote during his long career: 'una religio in rituum varietate.' In the history of the interpretation of these words, much effort has been made to explain them by connecting them to Western philosophical or Christian theological concepts. Yet efforts to elucidate the idea of 'one religion in a variety of rites' by Nicholas of Cusa's own metaphysics have not been successful, as Thomas McTighe has shown. ${ }^{1}$ This essay will therefore interpret Nicholas of Cusa's famous words by taking seriously the historical context in which Cusanus wrote them, namely, Christianity's encounter with Islam. Consequently, the bulk of this chapter will retrace the historical sources of the words 'one religion in a variety of rites' in the Qur'an, as well as its subsequent interpretation by Muslim scholars.

Because this new approach, centered on the Islamic sources of Nicholas's famous formula, is not unrelated to contemporary debates about his role in the encounter between Christianity and Islam, it may be good to start with a few remarks about Nicholas of Cusa's role in the contemporary Christian theology of religions. In his recent book Allah: A Christian Response, Miroslav Volf uses Nicholas of Cusa as a model of a positive approach to Islam. ${ }^{2}$ He points out that Nicholas was one of the few Christian theologians who preferred to react to the Fall of Constantinople in 1453 with words rather than weapons. Exchanging letters with his friend John of Segovia, Nicholas developed the idea of organizing a sort of interfaith conference, and his work De pace fidei ('On the Peace of Faith'), written almost immediately after the conquest of Constantinople, may be seen as a blueprint for such a conference. Even though Volf is careful not to take Nicholas of Cusa out of his historical context, it is easy to see how the words 'one religion in a variety of rites' tend to be explained as a

1 See Thomas McTighe, "Nicholas of Cusa's Unity-Metaphysics and the Formula Religio Una in Rituum Varietate," in Nicholas of Cusa in Search of God and Wisdom, ed. Gerald Christianson and Thomas M. Izbicki (Leiden: Brill, 1991), 161-72.

2 See Miroslav Volf, Allah: A Christian Response (New York: HarperOne, 2011), chapter two, "A Catholic Cardinal and the One God of All," 40-59. 
foreshadowing of the pluralist approach in the present-day Christian theology of religions, according to which the different religious traditions are limited expressions of one universal faith. ${ }^{3}$ Associating Nicholas with a contemporary form of religious pluralism that is most famously represented by John Hick or Wilfred Cantwell Smith also explains why theologians who are critical of such a pluralist approach also find Cusanus's words quite ambiguous. ${ }^{4}$ Both proponents and critics of Nicholas of Cusa in the theology of religions, however, agree that the idea of 'one religion in a variety of rites' can easily be interpreted in a pluralistic way. Yet research into the sources of these words will show that they convey a different form of pluralism. They go back to an annotation that Nicholas made in his personal copy of the so-called Toledan Collection, containing Latin translations of the Qur'an and a number of other Islamic writings. His annotation, fides una—ritus diversus ('one faith—different rites'), indeed reflects a specific Islamic — or rather, Qur'anic - way of looking at religious plurality. This chapter will explain the connection between Nicholas of Cusa and an Islamic view of religious pluralism in two parts. The first part considers the two works related to Islam in which Nicholas of Cusa writes about this idea of 'one religion in a variety of rites,' and the second part is concerned with his sources in the Qur'an and the history of its interpretation in the Islamic world as it came to be known in the Latin West.

\section{Nicholas of Cusa and the Fall of Constantinople}

Nicholas of Cusa (1401-1464) served the Church as a diplomat and Cardinal, and was involved in attempts to reunite the Western (Latin) and the Eastern (Greek) Church. In order to facilitate the negotiations for reunification, Nicholas visited Constantinople sixteen years prior to its conquest by the Ottoman Sultan Mehmet II in 1453. The knowledge of Islam that he gained during his stay in Constantinople, and more specifically the Latin translations that he gathered during his travels, would help him later to express his theological reflections on the Fall of Constantinople.

The first reflection, De pace fidei, written shortly after the fall, contained a fervent plea for peace between religions. In this fictitious dialogue between

3 I have recently explored this aspect further in my article "One Faith-Different Rites: Nicholas of Cusa's New Awareness of Religious Pluralism," in Understanding Religious Pluralism: Perspectives from Religious Studies and Theology, ed. Peter C. Phan and Jonathan Ray (Eugene, or: Wipf \& Stock, to be published in 2014).

4 See Karl J. Becker and Ilaria Morali, eds., Catholic Engagement with World Religions: A Comprehensive Study (Maryknoll, N.Y.: Orbis Books, 2010). 
representatives of many religions and cultures, Nicholas tests the possibility for a peaceful agreement. He introduces the notion of a utopian or eschatological ideal: how would the world be if all humans could know their Creator in one faith? What if they could recognize their differences as grounded in the same divine law or religion? Cusanus's literary fiction takes the form of a council, with which he was familiar as he had been present at the Council of Basel (1431). Yet Cusanus's fictitious meeting is not limited to Christians; its modern equivalent would be the League of Nations or the United Nations, with a large number of representatives of different nations. In religious terms, one could even think of the World Parliament of Religions in an eschatological setting, presided by the Word, by Christ himself. Cusanus introduces his fiction as follows:

After the brutal deeds recently committed by the Turkish ruler at Constantinople were reported to a certain man, who had once seen the sites of those regions, he was inflamed by a zeal for God; with many sighs he implored the Creator of all things that in his mercy he restrain the persecution, raging more than ever because of different religious rites. ${ }^{5}$

This man, in whom we might well recognize Cusanus himself, seems to be convinced that violence between religions can be overcome if religious practitioners would realize that their religious rites are in fact varieties of one basic faith: una religio in rituum varietate. In the imaginary story of De pace fidei, the King of heaven and earth receives a number of messengers who bring stories of religious strife and oppression. One of these messengers asks the heavenly King to manifest His face so that the enmity will end, and so all people will know that "there is only one religion in the variety of rites." ${ }^{\text {T }}$ This is the utopian ideal for Nicholas of Cusa: if only God would reveal Godself we would be able to acknowledge that we worship the same God in a variety of rites, and in that case all enmities between religions would cease. Here we come across a fun-

5 De pace fidei 1, 1: "Fuit ex hiis, quae apud Constantinopolim proxime saevissime acta per Turkorum regem divulgabantur, quidam vir zelo Dei accensus, qui loca illarum regionum aliquando viderat, ut pluribus gemitibus oraret omnium creatorem quod persecutionem, quae ob diversum ritum religionum plus solito saevit, sua pietate moderaretur." Latin text reproduced from the Heidelberg critical edition, and English translation by H. Lawrence Bond in: Nicholas of Cusa on Interreligious Harmony. Text, Concordance and Translation of De Pace Fidei, ed. James E. Biechler and H. Lawrence Bond (Lewiston, N.Y.: The Edwin Mellen Press, 1990), 3; hereafter cited as 'trans. Bond.'

6 De pace fidei 1, 6: "Si sic facere dignaberis, cessabit gladius et odii livor, et quaeque mala; et cognoscent omnes quomodo non est nisi religio una in rituum varietate"; trans. Bond, 7 . 
damental notion in the work of Nicholas the philosopher: the idea of learned ignorance. We know that ultimately we do not know God, and that we only know how God is worshipped in a variety of rites. But Nicholas is enough of a (church-)politician to add a healthy dose of realism here, and therefore adds:

But if perhaps this difference of rites cannot be removed or if it is not expedient to do so in order that the diversity may contribute to devotion ... at any rate, just as you are one, there should be one religion and one veneration of worship. ${ }^{7}$

As the editors of De pace fidei have noted, this is a clear allusion to a famous text from the Quran, which we will encounter again in the Cribratio Alkorani. ${ }^{8}$

In the debates between the representatives of the different nations, Nicholas of Cusa immediately broaches this theme of the unity and harmony of religions by letting the oldest representative, a Greek (clearly a reference to the importance of Greek philosophy), address this problem:

We give praises to our God whose mercy is above all his works; he alone is able to cause so great a diversity of religions to be brought into one concordant peace $[. .$.$] Therefore, we beseech you now to instruct us how$ this unity of religion could be introduced by us. ${ }^{9}$

After the Greek and an Italian, the third representative entering the discussion (presided by none other than the Word) is an Arab, who agrees with the others that all human beings by nature desire Wisdom. When he asserts that this Wisdom is the one God, the Word agrees and says: "Therefore, for all those who are of sound understanding there is one religion and worship, which is presupposed in all the diversity of the rites." ${ }^{\prime 10}$ Here the Word gives the formula

De pace fidei, "Quod si forte haec differentia rituum tolli non poterit aut non expedit, ut diversitas sit devotionis adauctio, quando quaelibet regio suis ceremoniis quasi tibi regi gratioribus vigilantiorem operam impendet: saltem ut sicut tu unus es, una sit religio et unus latriae cultus"; trans. Bond.

See notes 12 and 13 in Biechler and Bond, Nicholas of Cusa on Interreligious Harmony, $222-23$.

De pace fidei, 4, 10: "Laudes Deo nostro dicimus, cuius misericordia super omnia opera eius, qui solus potens est efficere quod in unam concordantem pacem tanta religionum diversitas conducatur... Oramus tamen nunc instrui, quo modo haec per nos religionis unitas possit introduci"; trans. Bond, 11.

10 De pace fidei, 6, 16: "Una est igitur religio et cultus omnium intellectu vigentium, quae in omni diversitate rituum praesupponitur"; trans. Bond, 15. See also James E. Biechler, 
in a somewhat elaborate form: "una est igitur religio et cultus ... quae in omni diversitate rituum praesupponitur." It is interesting to note that in these texts Nicholas of Cusa uses both the singular una religio and the plural diversitas religionum so that the word can be an equivalent of the one faith (fides) or worship (cultus) on the one hand, and of the multitude of rites (ritus) on the other. It would be interesting to further investigate this particular-and possibly unprecedented - use of the word religio as both a normative and eschatological ideal and as a description of existing plurality, since it seems to foreshadow much later conceptions of pluralism in the philosophy and theology of religions. ${ }^{11}$ Yet the introduction of a normative notion of orthodox faith to which all religions will be led in the first intervention by the incarnate Word seems to suggest otherwise: "Since truth is one and since it is not possible that it not be understood by every free intellect, all diversity of religions will be led to one orthodox faith."12 As we will see later, this tension between one orthodox faith and the multiplicity of religious rites corresponds to the tension in the Qur'an between the one divine law or religion revealed by God, and the many rites and customs brought by the prophets to the different nations. With this, we turn to the second major text that Nicholas of Cusa devoted to Islam.

While De pace fidei captures Nicholas's first reflection on the Fall of Constantinople, he came back to this event seven years later with a more elaborate theological reflection, in which he once again used the same idea about the variety of rites and the one faith. Having read the Qur'an in its Latin translation, he wanted to help Pope Pius II give a more theological answer to the Fall of Constantinople in the form of a letter to Sultan Mehmet, the Conqueror (al-Fatih) of Constantinople. Nicholas hoped that his Christian interpretation of the Qur'an would show that it in fact supports Christian claims about Jesus Christ, and might consequently convince the Sultan that he should convert to Christianity. In order to substantiate his proposal for a papal letter to the Sultan, Cusanus wrote a long theological treatise. This work, the Cribratio Alkorani or "Sifting of the Qur'an," is often seen as representing a much more polemical approach to Islam than the peaceful setting of De pace fidei. ${ }^{13}$ The literary form

"A New Face toward Islam: Nicholas of Cusa and John of Segovia," in Nicholas of Cusa in Search of God and Wisdom, ed. Gerald Christianson and Thomas M. Izbicki (Leiden: Brill, 1991), 185-202, here 197 .

11 This is what makes Nicholas of Cusa's use of the term ambiguous, according to the editors of Catholic Engagement with World Religions.

12 De pace fidei, 3, 8: "Quae [= veritas] cum sit una, et non possit non capi per omnem liberum intellectum, perducetur omnis religionum diversitas in unam fidem orthodoxam"; trans. Bond, 10.

13 See, among others, Norman Daniel, Islam and the West: the Making of an Image (1st ed. 1960; reprinted Oxford: Oneworld, 1993), 307. 
of this work differs as well, as Sifting of the Qur'an endeavors to approach the holy book of Islam with the mindset of a Christian theologian. However, in this work we come across the same words-'una religio in rituum varietate'-once again, which might indicate that the same form of pluralism is operative here as well. More importantly, Nicholas expressly identifies these words as pertaining to a specific Islamic way of looking at the plurality of messengers, and at the guidance given by God to humankind. Thus, it is this Islamic view on the history of prophecy and revelation that is behind Nicholas's familiar phrase: 'one religion in a variety of rites.'

At the beginning of the first book of the Cribratio Alkorani, Nicholas explains this Islamic point of view on religious plurality as follows:

[Followers of Muhammad] also say that God sent to all nations indigenous messengers and that [through them] He admonished these nations regarding what they had to believe and had to do in order to be numbered, on the day of judgment, among those who are good and in order to attain unto the Paradise full of joy. [. . .] Accordingly [followers of Muhammad] conclude that if the variety of laws and of rites is found to be present in the identity-of-faith that is exhorted within the various nations by the messengers of God, then indeed this [kind of diversity] cannot at all prevent one who is obedient from obtaining a fitting reward at the hands of the most gracious and most just Judge. ${ }^{14}$

Again, we meet here an eschatological vision of interreligious harmony, but this time the diversity is not to be overcome until God speaks the truth in the final judgment, since this variety is meant to teach humankind how to believe and to act faithfully. In a formula that sounds much like the famous words from De pace fidei, Cusanus has the Muslims say that the one faith can be found in the variety of laws and rituals prescribed by the prophets of God to the various nations, though it is intended as a hidden guidance that will be fully uncovered by God on the Day of Judgment. ${ }^{15}$ In the meantime, diversity serves as an incitement to do good, and in this way arrive at eternal bliss.

14 Cribratio Alkorani I, 2, n. 27; Latin text in Nicolai de Cusa Cribratio Alkorani (Opera omnia, vol. VIII), ed. Ludwig Hagemann (Hamburg: Felix Meiner, 1986), 27-28; translation in Jasper Hopkins, Nicholas of Cusa's De pace fidei and Cribratio alkorani: Translation and Analysis (Minneapolis: The Arthur J. Banning Press, 1994), 88.

15 Cribratio Alkorani I, 2, n. 27: "Quare concludunt, quod, si varietas legum vel rituum in identitate fidei in variis gentibus per dei nuntios praecepta reperiatur, hoc quidem oboedienti nequaquam, quominus apud piissimum atque iustissimum iudicem condignum praemium assequatur, obese poterit." 
At this place in the Cribratio Alkorani, Nicholas of Cusa summarizes what Muslims have to say about the Qur'an: it is a book that came down from heaven and tells about the unity of God and the plurality of books and prophets; thus, the Qur'an confirms the various messengers and books given by God before. And indeed, one can find a number of texts in the Qur'an that confirm Cusanus's summary here. A rather famous text from Surat al-Ma'ida (Qur'an 5:48), often mentioned by Muslims as an important source for thinking about religious pluralism, ${ }^{16}$ seems to correspond quite well with what Nicholas has his Muslim interlocutors say:

We have assigned a law (shirah) and a path (minhaj) to each of you. If God had so willed, He would have made you one community (ummatan wahidatan) but He wanted to test you through that which He has given you, so race to do good: you will all return to God and He will make clear to you the matters you differed about. ${ }^{17}$

Hence, the basic view on religious differences in the Qur'an is that God sent different messengers to different nations with their own rites and beliefs in order that they emulate one another in doing good, and God will in the end pass judgment over their differences.

\section{Sources for 'One Faith—Different Rites'}

Yet it would be quite a stretch to assert that Nicholas of Cusa received the inspiration for his idea about the God-given meaningfulness of religious plurality from the Quran. In order to make this assertion plausible, we need to go back from Nicholas of Cusa in the fifteenth century to Peter the Venerable and Hermann of Dalmatia in the twelfth century — one of the first encounters between the world of Islam and the world of the Latin West. From there, we

16 See Muhammad Shafiq and Mohammed Abu-Nimer, "The Qur'anic Perspectives of Interfaith Dialogue," in Interfaith Dialogue: A Guide for Muslims (Herndon, va: The International Institute of Islamic Thought, 2007), 49-84; Reza Shah-Kazemi, The Other in the Light of the One: the Universality of the Qur'an and Interfaith Dialogue (Cambridge: Islamic Texts Society, 2006). Some reflections also in Pim Valkenberg, Sharing Lights on the Way to God: Muslim-Christian Dialogue and Theology in the Context of Abrahamic Partnership (Amsterdam-New York: Editions Rodopi, 2006), 152-62.

17 Qur'an 5:48 in the interpretation by M. A. S. Abdel Haleem, The Qur'an: English Translation and Parallel Arabic Text (Oxford: Oxford University Press, 2010), 117. I added a transliteration of the most important Arabic words in this text. 
need to go back even further to 'Abdallah ibn Salām, believed to be an early Jewish convert to Islam in the seventh century, and finally, we will come to none other than Prophet Muhammad himself, in conversation with 'Abdallah ibn Salām.

We begin with Nicholas of Cusa and his copy of the Qur'an. In the introduction to the Cribratio Alkorani, Nicholas states that he made quite an effort to obtain a good Latin translation of the Qur'an. ${ }^{18}$ Since he could not read Arabic and his efforts to commission a Latin translation failed, in the end he had to settle for the twelfth-century translation by Robert of Ketton. This work was part of the so-called Toledan Collection, a number of translations commissioned by Peter the Venerable, Abbot of Cluny, in Toledo around 1140. ${ }^{19}$ Interestingly, Peter's translation project was inspired by the same idea as Nicholas' De pace fidei: to prefer the battle of words over the battle of arms - the Crusades-as reaction to the emerging political power of Islam. ${ }^{20}$ The Toledan collection was for a long time the main instrument for the Christian West to become acquainted with the world of Islam. Thus, it has been reprinted many times since its first printing in 1543 by the Reformed theologian Theodor Buchmann (or Bibliander) in Basel, with introductory essays by Martin Luther and Philipp Melanchthon. ${ }^{21}$ Writing a century before that though, Nicholas of Cusa used a manuscript copy of the collection, which can still be consulted today since it has been preserved in his own personal library as Codex Cusanus 108. James Biechler has made a careful study of this manuscript and has ventured the hypothesis that Nicholas studied the Qur'an and other writings associated with it, making notes in the margin of these works at least three times. ${ }^{22}$ The first notes date from the period in which Nicholas worked as a young canon

18 Cribratio Alkorani, prologue, nn. 2-4; translation in Hopkins, 75-76.

19 See James Kritzeck, Peter the Venerable and Islam (Princeton: Princeton University Press, 1964).

20 Kritzeck, Peter the Venerable and Islam, 21. For a similar comparison, see Rita GeorgeTvrtković, "After the Fall: Riccoldo da Montecroce and Nicholas of Cusa on Religious Diversity," Theological Studies 73 (2012): 641-62.

21 Kritzeck, Peter the Venerable and Islam, viii. A somewhat later edition from 1550 is reproduced on the internet by the Bibliothèque Nationale de France: gallica.bnf.fr. The first part of the title in Latin is: Machumetis Saracenorum principis ejusque successorum vitae, doctrina, ac ipse Alcoran. The text was reprinted by Les Mondes Humanistes (GRAC-UMR 5037) in 2010.

22 See James E. Biechler, "Three Manuscripts on Islam from the Library of Nicholas of Cusa," Manuscripta 27 (1983): 91-100. 
lawyer in Basel. ${ }^{23}$ The second series of notes is connected with the composition of De pace fidei in 1453, while the last series of notes is related to the meticulous preparation of the Cribratio Alkorani in 1460-61. One of the notes in the second series is of particular interest, since it seems to indicate the origins of the famous words, 'religio una in rituum varietate.' It is a note, together with a hand pointer, on fol. 25 of Codex Cusanus 108, which reads: "fides una, ritus diversus. ${ }^{24}$ Now, the work that inspired Nicholas to write this note was not the Latin translation of the Quran by Robert of Ketton, but rather an obscure Islamic treatise that formed part of the Toledan Collection, entitled Lex sive Doctrina Machumet (Law or Teaching of Muhammad) and translated by Hermann of Dalmatia in $1143 .{ }^{25}$

It is next to this text on the teaching of Muhammad that Nicholas of Cusa wrote 'fides una, ritus diversus.' Biechler comes to the conclusion that

Cusanus's note seems to be the root of his principle 'religio una in rituum varietate' expressing his theoretical solution to the problem of the world religions: there is really only one religion existing in a variety of rites or forms. ${ }^{26}$

Ludwig Hagemann, the German medievalist and editor of the Cribratio Alkorani, is even more outspoken about the importance of this marginal note, claiming: it is of great importance and without a doubt shows the source and origin of the phrase 'religio una in rituum varietate. ${ }^{27}$ The emphasis on Muslim sources in Hagemann's remark makes sense if one links the discussion about the origins of the famous phrase 'una religio in rituum varietate' to the history of its reception in the twentieth century. Various scholars have connected these words instead with neo-Platonic and other philosophical backgrounds, as well

23 For biographical information, see Erich Meuthen, Nicholas of Cusa: A Sketch for a Biography, trans. D. Crowner and G. Christianson (Washington, D.C.: The Catholic University of America Press, 2010).

24 Biechler, "Three Manuscripts," p. 94; Biechler, "Interreligious Dialogue," in Introducing Nicholas of Cusa: A Guide to a Renaissance Man, ed. C. Bellitto, T. Izbicki and G. Christianson (New York-Mahwah, N.J.: Paulist Press, 2004), 270-96, here 279.

25 See Guillaume Frédéric Pijper, Het boek der duizend vragen (Leiden: Brill, 1924), 4.

26 Biechler, "Three Manuscripts," 94-95.

27 Cribratio Alkorani 223, in note 77 on the text quoted earlier, I, 2, n. 27: "Verba fides una, ritus diversus' a Nicolao in margine adscripta magni ad illam Nicolai sententiam 'religio una in rituum varietate' (De pace 1 n.6) momenti sunt. Si quaeremus, quibus e fontibus ea doctrina hausta sit, dubium non potest esse, quin Doctrina fons et origo illius sententiae sit...." 
as with Catholic and other forms of ecclesiology. ${ }^{28}$ Against this tradition, I agree with Hagemann that a reference to Islamic sources makes much more sense if the formula is used by Nicholas in both De pace fidei and Cribratio Alkorani, and if it is used in the latter book in an explicit reference to what defenders of the Qur'an say. Yet the marginal note in itself does not necessarily indicate that Nicholas derived the formula from the Doctrina Machumet; he might simply have recognized a formula that he had met before as a student of canon law or conciliar history, as Erich Meuthen observes in a note on the historical sources of the formula. ${ }^{29}$ Yet Biechler's remark on the threefold series of notes in Cusanus's copy of the Toledan Collection suggests an even more interesting possibility, namely, that Nicholas noticed the formula for the first time in several sources when he was a student and young practitioner of canon law, but that this knowledge was activated when he went through the Collectio Toletana for the second time, looking for a solution to the problem of religious plurality occasioned by the Fall of Constantinople.

In any case, the presence of the hand pointer and the marginal note makes a strong case for an Islamic notion of unity-in-plurality behind the formula 'one faith, different rites,' which would have such a lasting influence through its rephrasing in De pace fidei. In order to see what exactly this Islamic notion of unity-in-plurality might be, we need to look at the Arabic text that was translated by Hermann of Dalmatia, one of the assistants of Peter the Venerable in the 1140s. The work is known in its Arabic original as the Kitāb al-masāill, or "Book of questions," attributed to 'Abdallah ibn Salām. The genre of this book is well known in early Islamic apologetics: a group of Jews (or Christians) comes to Prophet Muhammad and poses him some questions whose answers, according to their tradition, are known only to a true prophet. It is the goal of apologetic works such as these to show that the Jews in the text converted to Islam because Muhammad, being a true prophet, knew all the right answers,

28 For two good examples, see Maurice de Gandillac, "Una religio in rituum varietate," in Nikolaus von Kues als Promotor der Ökumene, ed. R. Haubst, Mitteilungen und Forschungsbeiträge der Cusanus-Gesellschaft, 9 (1971): 92-105; Michael Seidlmayer, "'Una religio in rituum varietate': zur Religionsauffassung des Nikolaus von Cues," Archiv für Kulturgeschichte 36 (1954): 145-207.

29 See Erich Meuthen, "Der Dialogus concludens Amedistarum errorem ex gestis et doctrina concilii Basiliensis," Mitteilungen und Forschungsbeiträge der Cusanus-Gesellschaft 8 (1970): 11-114, here 58-62. During the conference of the American Cusanus Society in Gettysburg in October 2012, Walter Euler remarked that Cusanus seems to use the formula about the one religion and the many rites already in his conversation with Bohemian (Hussite) representatives to the Council of Basel. See Meuthen, Nicholas of Cusa, 38-39. 
thereby suggesting that Jews who are confronted with this apology should do the same.

Even though the name of 'Abdallah ibn Salām is mentioned quite a few times in early Islamic sources, we do not currently possess a reliable Arabic text attributed to him. The reason is that the genre of the 'questions' lends itself to additions and changes, since later copyists and editors tended to add their own questions as well. Therefore, the Latin text translated by Hermann of Dalmatia is often considered to be the most reliable textual basis of this work. ${ }^{30}$ In this paper, I will first look at the significance of 'Abdallah ibn Salām in early Islamic sources; next, I will look at the Latin text that Nicholas of Cusa used; and finally, I will compare that text to a later-and unreliable-Arabic text version in order to see what exactly the Arabic terms could have been that occasioned Nicholas to write his note 'fides una-ritus diversus,' later reformulated as 'religio una in rituum varietate.'

'Abdallah ibn Salām is one of the few Jews who are looked upon favorably in early Islamic sources. The earliest source that mentions him is probably Ibn Ishaq's biography of Prophet Muhammad, written about two centuries after the death of the Prophet. In this biography (as handed down in the later version by Ibn Hisham), Ibn Ishaq mentions 'Abdallah ibn Salām, together with three other Jews, as rabbis who came to the true faith of Islam. Ibn Ishaq mentions this example as an explanation of the following verses in surah Al Imran (3:113-114):

They are not all alike; of the scripture folk there is an upright community who read God's verses in the night season prostrating themselves. They believe in God and the last day and enjoin good conduct and forbid evil and vie with one another in good works. They are the righteous. ${ }^{31}$

A little before that, Ibn Ishaq had told the conversion story of 'Abdallah ibn Salām in the following words:

I was told the story of 'Abdullah b. Salām, a learned rabbi, by one of his family. He said: 'When I heard about the apostle I knew by his descrip-

30 Pijper, Het boek der duizend vragen, 40. Kritzeck, Peter the Venerable and Islam, 73-74, describes a manuscript (MS 1162 of the Bibliothèque de l'Arsenal) that he believes to be the original Toledan Collection, written in Spain before 1150 and bound in Cluny shortly thereafter.

31 Quoted according to the English translation by A. Guillaume in The Life of Muhammad: A Translation of Ishaq's Sīrat Rasūl Allāh (Oxford-New York: Oxford University Press, 1955), 262. 
tion, name, and the time at which he appeared that he was the one we were waiting for, and I rejoiced greatly thereat, though I kept silent about it until the apostle came to Medina. When he stayed in Qubä' among the b. 'Amr b. 'Auf a man came with the news while I was working at the top of a palm-tree and my aunt Khālida b.al-Hārith was sitting below. When I heard the news I cried Allah Akbar and my aunt said: "Good gracious, if you had heard that Moses b. Imrān had come you could not have made more fuss!" "Indeed, aunt," I said, "he is the brother of Moses and follows his religion, being sent with the same mission." She asked, "Is he really the prophet who we have been told will be sent at this very time?" and she accepted my assurance that he was. Straightway I went to the apostle and became a Muslim, and when I returned to my house I ordered my family to do the same.

I concealed the matter from the Jews and then went to the apostle and said, "The Jews are a nation of liars and I wish you would take me into one of your houses and hide me from them. Then ask them about me so that they may tell you the position I hold among them before they know that I have become a Muslim. For if they know it beforehand, they will utter slanderous lies against me." The prophet housed me; the Jews came; and the apostle asked them about my standing among them. They said: "He is our chief and the son of our chief; our rabbi, and our learned man." When they said this, I emerged and said: "O Jews, fear God and accept what He has sent you. For by God you know that he is the apostle of God. You will find him described in your Torah and even named. I testify that he is the apostle of God, I believe in him, I hold him to be true, and I acknowledge him." They accused me of lying and reviled me. Then I reminded the apostle that I had said that they would do this, for they were a treacherous, lying and evil people. I publicly proclaimed my conversion and my household and my aunt Khālida followed suit. ${ }^{32}$

This rather long story teaches us three things about the relationship between the first Muslims and the Jewish community. First, the story functions as part of the anti-Jewish polemics in Medina, where a large majority of the important Jewish population was not ready to accept Muhammad as a prophet. In this context, the Qur'an and early Islamic tradition argue that most Jews are not to be trusted, in part because they do not read their own Scriptures properly. Second, as the text just quoted from the Qur'an mentions, there is a minority among the Jews who do know how to read the Scriptures and the signs of the times. They are the upright and the just ones, but they are of course 
also the ones who convert to Islam. Thus, 'Abdallah ibn Salām is portrayed as a leader of this community: he is the most learned scholar, and is able to read the announcement of the future prophet in the Jewish Scriptures. Finally, 'Abdallah ibn Salām is portrayed as someone who does not need to be convinced, as he just goes to Muhammad and converts to Islam. In fact, as later Muslims would say, he does not convert but he reverts to his true nature ( fitra) as muslim, someone who submits himself freely and willingly to God.

This final characteristic, viz. that 'Abdallah ibn Salām immediately converts without further questions, changes in subsequent traditions. The later traditions about the 'questions' posed by Ibn Salām to the Prophet have their origin in a hadith (a traditional story about Muhammad and his first followers) transmitted by Bukhari in the context of the stories of the prophets, in which the story about Ibn Salām serves to highlight the prophethood of Muhammad. Bukhari recounts:

Narrated Anas: when 'Abdullah ibn Salam heard of the arrival of the Prophet at Al-Madina, he came to him and said: "I am going to ask you about three things which nobody knows except a Prophet: (1) What is the first portent of the Hour? (2) What will be the first meal taken by the people of Paradise? (3) Why does a child resemble its father, and why does it resemble its maternal uncle?" Allah's messenger said: "Jibrael (Gabriel) has just now told me of their answers." "Abdullah said: "He, from amongst all the angels, is the enemy of the Jews." Allah's Messenger said: "The first portent of the Hour will be a fire that will collect the people from the east to the west; the first meal of the people of Paradise will be extra lobe (caudate lobe) of fish-liver. As for the resemblance of the child to its parents: If a man has sexual intercourse with his wife and gets discharge first, the child will resemble the father, and if the woman gets discharge first, the child will resemble her. On that, 'Abdullah bin Salam said: "I testify that you are the Messenger of Allah." 'Abdullah bin Salam further said: "O Allah's Messenger! The Jews are liars, and if they should come to know about my conversion to Islam before you ask them (about me), they would tell a lie about me." The Jews came to Allah's Messenger and 'Abdullah went inside the house. Allah's Messenger asked (the Jews) "What kind of man is 'Abdullah bin Salam amongst you?" They replied, "He is the most learned person amongst us, and the best amongst us, and the son of the best amongst us." Allah's Messenger said: "What do you think if he embraces Islam?" The Jews said: "May Allah save him from it." Then 'Abdullah bin Salam came out in front of them saying, "I testify that La ilaha ill-Allah (none has the right to be worshipped but Allah) and 
Muhammad is the Messenger of Allah." Thereupon they said, "He is the most wicked among us, and the son of the most wicked among us," and continued talking badly of him. ${ }^{33}$

A new element in this hadith is the enmity between the Jews and Jibrill or Gabriel, the angel that functions as an important messenger of God and mediator of God's revelation in Islam and Christianity. Ibn Kathīr, who uses stories from the hadith collections many times to interpret the Qur'an, uses this particular story to explain the meaning of the Qur'anic verse: "Whoever is an enemy to Jibril, because he has brought it [the Qur'an] down to your heart."34 Yet this new element serves to underline the common point in the two stories, which is the trustworthiness of 'Abdallah ibn Salām in contrast to the moral depravity of most other Jews. 'Abdallah ibn Salām is so noteworthy precisely because he represents an exceptional case of a trustworthy Jew who converts to Islam. This same point is made in an English translation of the Qur'an published by the same publishing house from Saudi Arabia, where the reference to 'Abdallah ibn Salām is even translated into the text, with a footnote that gives the text just quoted from Bukhari. ${ }^{35}$ Hence, it is clear that in a traditional Islamic reading of the Qur'an, 'Abdallah ibn Salām is well known as one of the few Jews who converted to Islam because he believed in the prophethood of Muhammad. Consequently, according to another tradition, Ibn Salām is praised by Muhammad as one of the 'men of paradise.'36

33 Quoted with some omissions from Summarized Sahîh Al-Bukhâri Arabic-English, translated by Dr. Muhammad Muhsin Khan (Riyadh: Darussalam, 1996/1417), no. 1400, 658-59 (no. 4:546 in the original Sahîh Bukhâri).

34 See Tafsir ibn Kathir, abridged, vol. I (Riyadh: Darussalam, 2003), 305, with reference to Qur’an 2:97.

35 In this translation, Qur'an 5:66 goes as follows: "And if only they had acted according to the Taurāt (Torah), the Injil (Gospel), and what has (now) been sent down to them from their Lord (the Qurān), they would surely, have gotten provision from above them and from underneath their feet. There are from among them people who are on the right course (i.e. they act on the Revelation and believe in Prophet Muhammad ... as 'Abdallah bin Salam...), but many of them do evil deeds." Quoted from Dr. Muhammad Muhsin Khan and Dr. Muhammad Taqi-ud-Din Al-Hilali, Interpretation of the Meanings of the Noble Qurân in the English Language (Riyadh: Darussalam, 1996), 165-66.

36 The tradition is in the collection by Muslim. For the reference, see Ronit Ricci, "A Jew on Java, a Model Malay Rabbi and a Tamil Torah Scholar: Representations of Abdullah Ibnu Salam in the Book of One Thousand Questions," Journal of the Royal Asiatic Society, series 3/18 (2008): 481-95. 
The importance of 'Abdallah Ibn Salām for early Islamic apologetics comes into focus by a remark often repeated in early Muslim sources, namely, that Jews seldom convert to Islam while Christians convert-or, as Muslims would say, revert - to Islam more frequently. The traditionalist Ibn Kathir, for instance, explains in reference to Qur'an 3:199: "There are, certainly, among the People of the Scripture, those who believe in Allah and in that which has been revealed to them, humbling themselves before Allah": "These qualities exist in some of the Jews, but only a few of them. For instance, less than ten Jewish rabbis embraced the Islamic faith, such as 'Abdullāh ibn Salām. Many among the Christians, on the other hand, embraced the Islamic faith."37

Sometimes 'Abdallah ibn Salām is mentioned by name with reference to places where the Quran talks about some of the People of the Book who accepted the revelation brought to Muhammad. For instance, Al-Wāhidi, in his Asbāb al-Nuzūl (the traditional work on the "Occasions of the Revelations"), connects 'Abdallah with the following verse: "Those unto whom We gave the Scripture recognize (this revelation) as they recognize their sons" (Qur'an 2:146). Furthermore, he states:

This was revealed about the believers of the People of the Book: 'Abd Allah ibn Salam and his companions ... Said 'Abd Allah ibn Salam: 'I knew Allah's Messenger ... better than I knew my son.38

Other reports tell how 'Abdallah still observed the customs of the Torah after becoming a Muslim, so that he is mentioned as an authority about a number of Jewish customs, the so-called Isra'iliyyāt. ${ }^{39}$

Because of Ibn Salām's important function as one of the few people who connected the values, customs, and expectations of Judaism with the religion of Islam in a positive way, his name was associated with a much later literary tradition in which the questions he posed to Muhammad became the nucleus of an extended series of questions that were to show the truth of the Islamic

Tafsīr ibn Kathir, abridged, II (Riyadh: Darussalam, 2003), 358.

38 See Mokrane Guezzou, trans., Al-Wāhidìs Asbāb al-Nuzūl, Great Commentaries on the Holy Qur’an, vol. III (Louisville, KY: Fons Vitae, 2008), 18.

Other places where Abdallah is mentioned as one of the believers from the People of the Book are Qur'an 3:113 and 4:136. See Al Wahidi, Asbāb al-Nuzūl, 56 and 88. For the tafsìr concerning Qur'an 3:113 ("There are among the People of Scripture an upright community reciting God's revelations through the watches of the night as they bow down"), see also Mahmoud Ayoub, The Qur'an and Its Interpreters, vol. II: The House of Imran (Albany: State University of New York Press, 1992), 296-300. 
faith in answer to Jewish (and other) questions of several kinds. This tradition developed in many forms, ${ }^{40}$ one of which was translated by Hermann of Dalmatia into Latin, the language in which Nicholas of Cusa came to read it in his copy of the Toledan Collection.

Hermann of Dalmatia's Doctrina Mahumet describes how while in Medina, Muhammad is informed by Gabriel that a delegation of four Jewish religious leaders, led by 'Abdia iben Salon' ('Abdallah ibn Salām), is about to visit him. ${ }^{41}$ Abdia explains that he has come to question Muhammad about things that are not clear in their Jewish faith. The first question is: "Are you a prophet (propheta) or a messenger (nuncius)?" Muhammad replies: "God has made me both a prophet and a messenger." Next, Abdia asks: "Do you preach your law or the law of God (lex Dei)?" When Muhammad answers that he preaches the law of God, Abdia asks what this law is, and Muhammad answers: "Faith (fides)." When asked which faith, Muhammad responds with the two basic tenets of monotheism and resurrection of the dead. Abdia then asks: "How many laws of God are there?" Muhammad responds: "There is one law of God." "But what about the prophets that have come before you?" asks Abdia, to which Muhammad replies: "The law or the faith of the prophets is one, but the rites of the different ones were of course different" (Lex quidem, siue fides, omnium una, sed ritus diuersorum nimirum diuersi). The discussion then goes on about whether people can attain paradise by faith, by certain beliefs, or by works (pro fide, aut credulitate, aut pro opere). This discussion in the Doctrina Mahumet comes close to the context and the terminology of Qur'an 5:48 (surah al-Maida), which Nicholas of Cusa quoted at the beginning of his Cribratio Alkorani: God could have made us one community, but He has given us different rites and customs in order for us to rival one another by doing good, and in the end God will pass judgment about the differences.

After this short discussion about these fundamental issues in Islamic theology, the Latin text of the Doctrina Mahumet continues with a discussion of the book that Muhammad claims to have received from God, and then it goes on with a number of seemingly disconnected issues: questions about the meaning of numbers, about God's creation of the heavenly bodies, and riddles such as "what woman came forth only from a man, and what man only from a woman?" What these seemingly disparate matters have in common is that regular human beings do not know the truth about them, but a true prophet

\footnotetext{
$40 \quad$ See Pijper, Het boek der duizend vragen, and Ricci, "A Jew on Java."

41 In the following paragraph, English paraphrases are mine; the Latin words are from the Bibliander edition on the internet, http://gallica.bnf.fr/ark:/12148/bpt6k114531g/f214. image; see footnote 21), fol. 189-190.
} 
would know how to answer the questions and riddles. Since Muhammad succeeds in responding to Abdia's challenges, the Jewish delegation accepts that he is a true prophet and consequently converts to Islam. This means that the remark about the one law of faith and the diversity of rites also functions in the context of what we may call Islamic 'prophetology,' which has always been one of the foremost issues in dialogues and apologetics between Muslims and Jews, for instance in the Kuzari by Judah Halevi. ${ }^{42}$

In order to find out what the phrase in Islamic theology was that Hermann of Dalmatia translated as 'Lex quidem, siue fides, omnium una, sed ritus diuersorum nimirum diuersi,' it would be nice if one could go back to the Arabic text of the Masāill. Unfortunately, though, the history of the genre of apologetic 'questions' is very complicated, and so we do not possess any original form of the text or any critical edition. ${ }^{43}$ I have been able to read one version of an Arabic text attributed to Ibn Salām on the Internet, which represents a much later adaptation of the text and reflects a stricter form of Islamic apologetics than the text translated by Hermann of Dalmatia. However, one may assume that the basic concepts have been preserved, even if the theological context in this Arabic version represents a later development.

When going back to the Arabic roots of the Latin phrase about the one lex or fides and the diversity of ritus, one will find that it matches perfectly with Islamic prophetology: Muslims believe in a plurality of prophets and scriptures, because God has revealed God's guidance at different times to different nations that each have their own rites. Yet, at the same time, there is only one true faith, which is - in accordance with the apologetic style of this Arabic adaptation-immediately identified with the religion of Islam. In answer to 'Abdallah Ibn Salām's question about the message that he brings as prophet and messenger, we find Muhammad saying, according to the Arabic text:44 "There is one din" - a word that is usually translated as 'religion,' but 'Law' is possible as well because the word refers to the 'Law of God.' In medieval Latin, the word lex is often used where modern readers would expect 'religion. ${ }^{\prime 5}$ Muhammad

42 See the introductory remarks by Barbara Roggema, Marcel Poorthuis, and Pim Valkenberg in The Three Rings: Textual Studies in the Historical Trialogue of Judaism, Christianity and Islam (Leuven: Peeters, 2005).

43 See Kritzeck, Peter the Venerable and Islam, 89.

44 I quote a contemporary Arabic version on the Internet, which represents a more advanced stage of Islamic theology, as most Arabic text versions do (see Pijper, Het boek der duizend vragen, 39.) The text quoted can be found on: cb.rayaheen.net/showthread. php?tid=27739.

45 I want to thank Dr. Thomas Burman for bringing this to my attention during the conference of the American Cusanus Society in Gettysburg, October 2012. The very title of Hermann of Dalmatia's translation, Lex sive doctrina Mahumeti, is a case in point. 
continues: "The religion of the prophets was the pure religion of God, the religion of His angels, and the religion of Islam."46 When 'Abdallah ibn Salām then asks how many religions (or Laws) of God there are, Muhammad answers: "One religion, and that is Islam." ${ }^{47}$ In this later adaptation of the text, the word islām in Arabic is interpreted as referring to the institutionalized religion of Islam rather than to an attitude of faith, of submitting (or rather, aligning) oneself to God's will and guidance. But in older text versions of the Masāill, the attitude of faith might be the subject under discussion, since the text makes the famous distinction between isläm as the enacting of the five pillars, and imān (belief) as holding the six basic tenets of the faith. ${ }^{48}$

After this discussion, Abdallah wants to know how many paths or ways there are- the question 'how many?' refers back to similar questions concerning the number of prophets. He uses the Arabic word shir'ah, which literally refers to a path to the water well, which is essential for survival in the desertthe word shariah is derived from the same root. ${ }^{49}$ Muhammad answers: "There were different paths (or laws) with the peoples of the past." ${ }^{\prime 50}$ So we have two words, din and shir'ah, that can both be translated as 'law,' and it is precisely this ambiguity that defines the issue at hand between Abdallah and Muhammad. It creates a tension that is germane to Islamic theology: there are many customary laws (plural: shara $\bar{a} i$ ), while at the same time there is only one Law of God. Again, in the context of Jewish-Muslim dialogue one is reminded of the role of Jewish halakhah, the 'way to walk' and enact the Torah of God.

The theology in this Arabic text is clearly not pluralist, as it immediately identifies the one religion or din of the prophets with the established religion of Islam. However, one can still recognize the Quranic theology of religions from surah al-Maida (5:48) here, in the verse that gave Nicholas of Cusa occasion to make his remark about fides una, ritus diversus in his Cribratio Alkorani: "If God had willed, He could have made you one community, but He has given each of you a law and a way, ${ }^{51}$ and He will judge about the differences on the day of the resurrection." So, fides una, ritus diversus is a translation of din wāhid, sharā'i' (or manāhij) mukhtalifa: there is one religion revealed by God,

على دين الله الخالصودين ملائكته ودين الإسلام 46

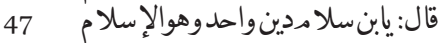

48 This distinction goes back to the famous "hadith of Gabriel" quoted by Muslim and Bukhari in the "book of faith" in their hadith collections. The famous book by Sachiko Murata and William C. Chittick, The Vision of Islam (St. Paul, MN: Paragon House, 1994) is built around the distinction between islam, iman and ihsan according to this hadith. كركانت الشرائع

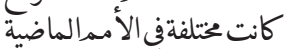

51 Murata and Chittick, The Vision of Islam, 133, translate: "We have appointed a right way and an open road." 
but there are different ways or customs or rites in which this religion is enacted by the different peoples. ${ }^{52}$ In Nicholas of Cusa's De pace fidei, this ambiguity of the notion of Law (din in the singular, or sharä $\imath^{\prime}$ in the plural) translates into an ambiguity in the notion of religion (lex / fides / cultus / religio in the singular; ritus / religiones in the plural). This translation is possible, however, because both in the Qur'anic theology of religions and in Cusanus's Christian theology of religions, there is an identity-in-tension between the one proper religion willed by God as the ultimate destination of humankind, and the diversity of religions willed by God as a way to learn from one another and to reach peace and harmony between religions, which is the horizon of the eschatological vision in De pace fidei.

$5^{2}$ Michel Cuypers, The Banquet: A Reading of the Fifth Sura of the Qur'an (Miami, Fl: Convivium, 2009), 242 remarks that the word minhaj ('path') in 5:48 "in its technical meaning of 'religious custom,' way of life, is borrowed from rabbinical language." The same is true for the entire Masā'il: Muhammad responds to Jewish questions about religion and laws. 